\title{
DYNAMICS CONNECTION OF SOUNDSCAPE WITH ARCHITECTURAL ELEMENTS \\ CASE STUDY: THE SEVEN SORROWS OF VIRGIN SAINT MARY \\ CHURCH
}

\author{
1'Javier Johnson. ${ }^{2}$ Roni Sugiarto, S.T., M.T. \\ ${ }^{1}$ Student in the Bachelor's (S-1) Study Program in Architecture \\ at Parahyangan Catholic University \\ 2 Senior lecturer in the Bachelor's (S-1) Study Program in Architecture \\ at Parahyangan Catholic University
}

\begin{abstract}
Nowadays, spatial experience still plays important role in the making of the good quality of architectural spaces. The experience of the space is a multi-sensory experience, so architecture should emphasize its attention not only to visual experience but also other experience like auditory experience. The study was conducted to determine the dynamics connection of soundscape experience and The Seven Sorrows of Virgin Saint Mary Church, Pandu Street, Bandung.

The research method is qualitative and descriptive analysis. The analysis is done through questionnaire distribution, field observation, analysis, and by relating it with the study of theories about church architecture, soundscape, sense of place, intention of architecture, and perception theory.

In The Seven Sorrows Of Virgin Saint Mary Church are found quite a lot of source of noise which are considered as sounds that decline the quality of the people spatial experience. The noise sounds that are found there are the sound of airplane, motor vehicle, and many more. Those noises can disturb the praying activity. This indicates that there are some architectural elements that have not been able to work optimally. It can be the material, activity settings, building and site shape or character. Furthermore, relation between activity schedule and noises climax will be analized.

Through design that concern in the multi-sensory aspects of experience, especially in auditory experience, the experience of space can be felt thoroughly and the quality of a public space can be increased.
\end{abstract}

Key Words: Soundscape, Architectural Elements, Church, The Seven Sorrows of Virgin Saint Mary Church

\section{DINAMIKA KETERHUBUNGAN SOUNDSCAPE DENGAN ELEMEN ARSITEKTURAL STUDI KASUS: KOMPLEK GEREJA SANTA PERAWAN MARIA SAPTA KEDUKAAN}

\author{
${ }^{1}$ Javier Johnson. ${ }^{2}$ Roni Sugiarto, S.T., M.T. \\ ${ }^{1}$ Mahasiswi S1 Program Studi Arsitektur Universitas Katolik Parahyangan \\ ${ }^{2}$ Dosen Pembimbing S1 Program Studi Arsitektur Universitas Katolik Parahyangan
}

\begin{abstract}
Abstrak- Pada masa sekarang pengalaman ruang masih memegang peran yang penting dalam pembentukan kualitas ruang arsitektur. Pengalaman ruang tersebut bersifat multiindera, sehingga arsitektur seyogyanya menekankan perhatiannya tidak hanya pada pengalaman visual namun juga pengalaman lainnya seperti pengalaman audial. Penelitian dilakukan untuk mengetahui dinamika keterhubungan pengalaman soundscape terhadap arsitektur pada Komplek Gereja Santa Perawan Maria Sapta Kedukaan di Jalan Pandu, Bandung.
\end{abstract}

\footnotetext{
${ }^{1}$ Corresponding Author: bernardusjj@yahoo.com
} 
Metode penelitian yang dilakukan adalah secara kualitatif dan analisis deskriptif. Analisa dilakukan melalui hasil pembagian kuesioner, observasi lapangan, analisis, dan menghubungkannya dengan kajian teori tentang arsitektur gereja, soundscape, sense of place, intention of architecture, dan teori persepsi.

Pada Komplek Gereja Santa Perawan Maria Sapta Kedukaan, ditemukan beberapa sumber bising yang memungkinkan menurunkan kualitas pengalaman ruang pengunjung. Suara tersebut diantaranya suara pesawat, kendaraan bermotor, dan lainnya. Hal itu dinilai mengganggu jalannya aktivitas peribadatan di sana sehingga mengindikasikan elemen arsitektur yang belum bekerja dengan maksimal baik dari segi penggunaan material, tata letak fungsi, bentuk dan karakter bangunan maupun tapaknya. Lebih lanjut, akan dikaji pula kesesuaian antara waktu pelaksanaan ibadah dengan titik kebisingan yang ada.

Melalui perancangan yang memperhatikan aspek pengalaman multi-indera khususnya dalam auditory experience, pengalaman ruang dapat dirasakan secara menyeluruh dan kualitas suatu ruang arsitektur dapat meningkat.

Kata kunci: Soundscape, Elemen Arsitektural, Gereja, Gereja Santa Perawan Maria Sapta Kedukaan

\section{PENDAHULUAN}

Pengalaman ruang sangat erat kaitannya dengan panca indera manusia karena dengan itulah manusia menerima informasi di sekitar lingkungannya. Namun pengalaman ruang terkadang hanya dipersepsikan dari apa yang terlihat oleh mata (visual). Padahal indera yang lain pun turut serta dalam memberi persepsi atas pengalaman ruang yang dirasakan, salah satunya indera pendengaran yang dapat mempersepsikan jarak tempat, waktu, dan material yang turut memperkaya pengalaman arsitektur. Maka lahirlah konsep soundscape yang dicetuskan oleh Schafer pada tahun 1977.

Berkaitan dengan soundscape tersebut, perkembangan teknologi dan pembangunan lingkungan binaan manusia yang semakin marak berbanding lurus dengan peningkatan bising dan tentunya mempengaruhi pengalaman soundscape suatu karya arsitektur termasuk tempat peribadatan seperti gereja. Gereja merupakan suatu fungsi yang dikenal secara umum membutuhkan kenyamanan audial yang baik serta dukungan soundscape yang erat dan khas. Soundscape khas yang dimaksud adalah perasaan sakral (sacred feeling) yang umunya terasa di dalam gereja karena adanya nilai-nilai religiusitas pada aktivitas yang dilakukan.

Salah satu contoh yang bisa kita lihat adalah fenomena yang terjadi pada Komplek Gereja Katolik Paroki Santa Perawan Maria Sapta Kedukaan, Jalan Pandu No 4, Bandung. Lokasi komplek gereja yang berdiri tahun 1935 ini berdekatan dengan Bandar Udara Husein Sastranegara Bandung dan dilalui oleh jalur pesawat terbang sehingga deru suara pesawat terbang sangat terdengar di komplek ini. Hal tersebut mempengaruhi soundscape Gereja Santa Perawan Maria Sapta Kedukaan.

Dari fenomena tersebut didapatkan pertanyaan penelitian sebagai berikut:

a. Bagaimana pengaruh suara yang dihasilkan oleh Gereja Santa Perawan Maria Sapta Kedukaan terhadap soundscape lingkungan sekitarnya?

b. Bagaimana hubungan antara elemen arsitektural dengan soundscape pada Kompleks Gereja Santa Perawan Maria Sapta Kedukaan Bandung?

c. Bagaiman hubungan antara elemen arsitektural dengan soundscape terhadap estetika perkotaan lingkungan Komplek Gereja Santa Perawan Maria Sapta Kedukaan Bandung?

Penelitian ini bertujuan untuk mengetahui hubungan antara elemen arsitektural dengan soundscape serta pengaruhnya terhadap pendengar, lingkungan sekitar, dan estetika perkotaan di sekitarnya.Selain itu, penilitian ini bermanfaat untuk menambah wawasan di bidang arsitektur mengenai soundscape tempat peribadatan khususnya gereja, memberi pemahaman 
pentingnya pengalaman multi-indera (khususnya auditory experience), dan menjadi referensi dalam perancangan lingkungan gereja yang memperhatikan audial experience.

Objek penelitian adalah Kompleks Gereja Paroki Santa Perawan Maria Sapta Kedukaan, sebuah gereja Katolik di kota Bandung yang sudah berdiri sejak 10 Mei 1935 dan masih aktif hingga sekarang. Beralamat di Jl. Pandu Nomor 4, Pamoyanan, Cicendo, Kota Bandung, Jawa Barat. Ruang-ruang yang akan diteliti melingkupi ruang yang biasa digunakan untuk fungsi ibadah yakni ruang dalam gereja, area parkir, area goa Maria, dan ruang adorasi yang dibagi menjadi 11 titik penelitian dengan karakteristik lokasi dan elemen arsitekturalnya masing-masing.

Untuk mengetahui pengaruh suara dari gereja terhadap soundscape yang terbentuk di lingkungan sekitarnya, fungsi-fungsi di sekitar gereja dengan radius 50 meter juga akan diamati. Fungsi-fungsi tersebut antara lain sekolah, sekretariat, gedung pastoran, biara, klinik kesehatan, area penjual bunga, perumahan warga, yang akan dijelaskan lebih lanjut pada bab berikutnya.

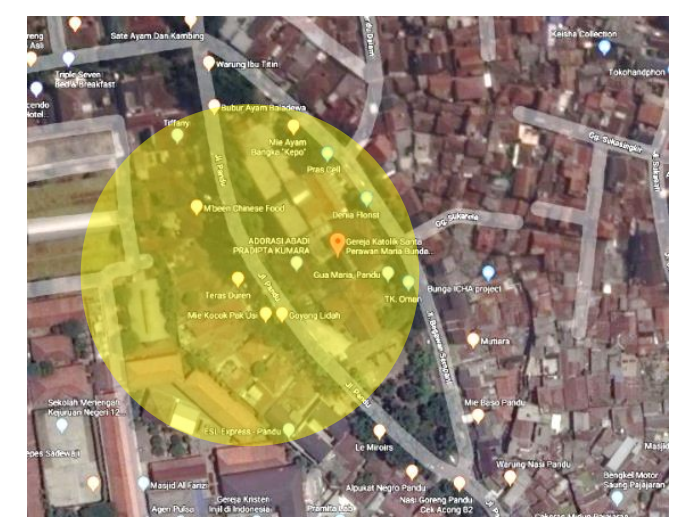

Figur 1. Cakupan ruang lingkup objek penelitian
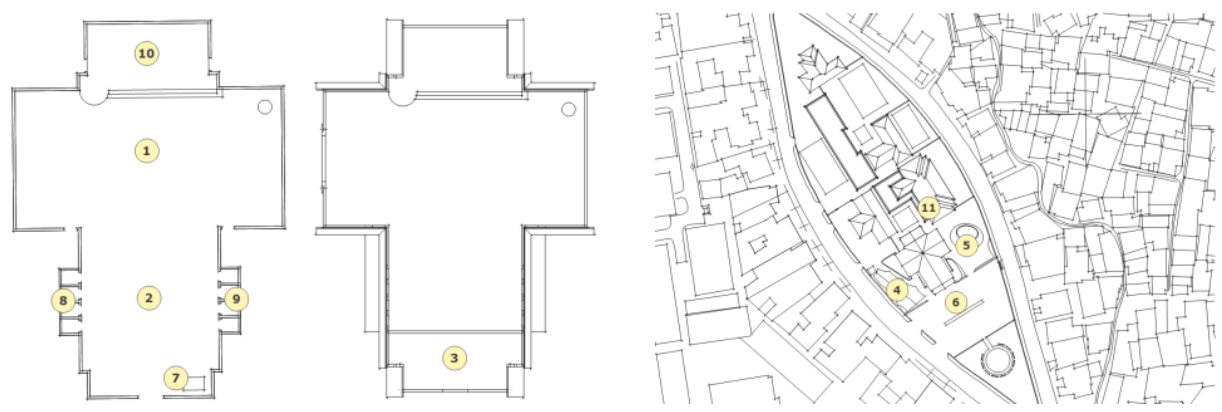

Figur 2. Lokasi titik-titik penelitian

Metode yang digunakan adalah metode kuantitatif, data diperoleh dari studi literatur, pengamatan dan pengukuran langsung ke lapangan, serta dari kuesioner dan wawancara terhadap pengunjung dan warga sekitar komplek gereja.

\section{TEORI SOUNDSCAPE PADA PENGALAMAN RUANG DI GEREJA KATOLIK}

\subsection{Soundscape}


Soundscape dapat diartikan sebagai kondisi akustik suatu lingkungan dengan penekanan pada bagaimana bunyi tersebut diterima dan dipahami oleh masing-masing individu maupun kelompok sesuai persepsi masing-masing ${ }^{2}$.

Soundscape merupakan bagian dari akustik lingkungan dan terdapat tiga elemen utama mengenai soundscape yaitu ${ }^{3}$ :

- Keynote sound merupakan suara-suara yang mungkin dengan kesadaran penuh tidak kita dengar tetapi dapat mempengaruhi karakter masyarakat disekitarnya. Biasanya suara-suara yang pada elemen keynote sound ini dihasilkan oleh alam, seperti suara air, suara angin, suara burung, atau suara lalu-lalang kendaraan.

- Sound signal, yaitu suara-suara yang secara sadar dapat kita dengar, seperti suara lonceng atau sirine.

- Soundmark merupakan elemen ketiga yang dianggap unik dan biasanya menjadi penanda sebuah daerah/ wilayah. Contoh soundmark adalah suara adzan yang menandakan akan segera dimulainya kegiatan beribadah umat islam (sholat), dan sebagainya.

Adapun berdasarkan sumber dan jenis suara yang ada, maka suara diklasifikasikan menjadi beberapa jenis, yaitu suara dari alam (natural), suara manusia, suara lingkungan, suara mekanikal, dan suara sebagai indikator. Ada 23 jenis sumber suara yakni geophony, biophony, dan anthrophony ${ }^{4}$.

\subsection{Persepsi}

Persepsi adalah proses mengatur, mengidentifikasi, dan menafsirkan informasi sensoris guna memberikan gambaran dan pemahaman bagi lingkungan ${ }^{5}$. Persepsi melibatkan semua sinyal pada sistem saraf, yang merupakan hasil stimulasi fisik atau kimia organ penginderaan. Seperti misalnya penglihatan yang merupakan cahaya yang mengenai retina mata, pencium yang memakai media molekul bau (aroma), dan pendengaran yang melibatkan gelombang suara. Persepsi bukanlah penerimaan isyarat secara pasif, tetapi dibentuk oleh pembelajaran, ingatan, harapan, dan perhatian ${ }^{6}$.

Proses terjadinya persepsi terdiri dari beberapa tahap yaitu :

1. Stimulus atau rangsangan

Persepsi terjadi ketika reseptor atau indera seseorang menerima stimulus atau rangsangan yang ada di lingkungan sekitarnya.

\section{Registrasi}

Seseorang dapat mendengar, melihat, meraba, dll bila informasi yang ditangkap reseptor individu tersebut kemudian mendaftarkan semua informasi tersebut.

3. Interpretasi

Interpretasi adalah proses memaknai atau memberikan arti kepada stimulus-stimulus yang diterima indera. Proses ini bergantung pada cara pendalaman, motivasi dan kepribadian individu.

\subsection{Akustik dalam Arsitektur}

\footnotetext{
2 B. TRUAX, Handbook for Acoustic Ecology; A.R.C. Publication: Vancouver, Canada, 1978, hlm. 93

3 SCHAFER RM, The Tuning of The World. New York: Alfred A. Knopf, 1977, hlm. 52

${ }^{4}$ BERNIE KRAUSE, Soundscape Ecology: The Science of Sound in the Landscape. Indiana: Purdue University, 2013, hlm. 204

5 DANIEL SCHACTER, Psychology, Worth, New York, 2011, hlm. 99

${ }^{6}$ RICHARD GREGORY, Concepts and Mechanisms of Perception, Duckworth, London, 1974, hlm. 156
} 
Akustik dalam arsitektur adalah sebuah ilmu teknologi dari mendesain sebuah ruang, struktur, dan sistem mekanikal untuk mencapai kebutuhan pendengaran. Suara dapat mencapai penerimanya melalui media perantara. Media/perantara dari bunyi/suara ini dapat berupa gas, benda padat, ataupun cair. Secara umum jika suatu berkas bunyi/suara jatuh pada permukaan sebuah benda, bunyi/suara tersebut pasti akan mengalami 3 peristiwa, yaitu:

- $\quad$ Refleksi bunyi (sound reflection)

- Absorbsi bunyi (sound absorbtion)

- $\quad$ Transmisi bunyi (sound transmission)

Peristiwa tersebut dapat terjadi satu persatu, namun gabungan antara kedua atau ketiga peristiwa tersebut juga sangat dimungkinkan dan masih sering terjadi (umum terjadi). Ketiga peristiwa ini adalah gejala yang umumnya dapat terjadi dalam sebuah ruang akustik. Peristiwa tersebut selalu dapat dimanfaatkan, atau mungkin kadang perlu dihindari, dalam pola pengolahan suara bagi kelayakan akustik dalam suatu ruangan ${ }^{7}$.

Dalam hal mengendalikan dan mengondisikan bunyi maupun bising sifat material juga akan sangat berpengaruh. Setiap material memiliki sifatnya masing-masing yang bisa meneruskan, menyerap, atau menantulkan suara. Oleh karena itu setiap material memiliki koefisien absorbsi suara yang identik sesuai dengan jangkauan frekuensi suara tertentu.

\subsection{Sense of Place}

Sense of place adalah pengalaman khusus yang dialami seseorang pada lokasi dan waktu tertentu (setting), seperti mengalami perasaan tertarik pada suatu tempat, bahagia, dan sebagainya. Sense of place bagaikan hubungan aksi-reaksi, dimana ketika seseorang berinteraksi dengan sebuah tempat pada waktu tertentu kemudian akan menghasilkan reaksi. Reaksi yang ditimbulkan berupa perasaan, persepsi, tingkah laku, dan segala sesuatu yang terkait dengan keberadaan seseorang di tempat tertentu. Jadi 3 hal penting yang sangat mempengaruhi sense of place yaitu manusia, lingkungan (arsitektur dan tempat), dan interaksi yang terjalin diantara ketiga hal tersebut. Untuk mengalamai sense of place, kondisi panca indera, fokus, dan suasana hati seseorang perlu diperhitungkan ${ }^{8}$.

Beberapa karakter utama yang dapat menjadi acuan untuk menilai sense of place yaitu Identity, History, Fantasy, Mystery, Joy, Surprise, Security, Vitality, dan Memory. Ia juga mengungkapkan bahwa sense of place merupakan reaksi terhadap setting yang merangsang seseorang. Reaksi tersebut merupakan hasil dari setting serta aspek-aspek tertentu yang seseorang tersebut bawa ${ }^{9}$.

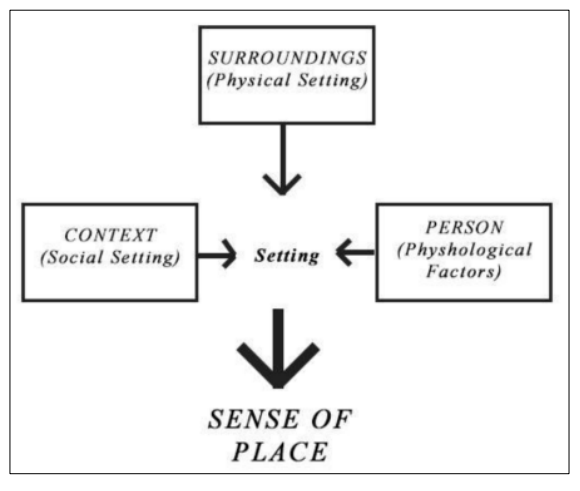

Bagan 1. Sense of Place

Sumber: Steele, 1981

\footnotetext{
7 HANDOKO SUTANTO, Prinsip-prinsip Akustik dalam Arsitektur, Kanisius, Yogyakarta, hlm. 5

8 JUHANI PALLASMAA. The Eyes of The Skin. Helsinki:Wiley, 1996, hlm. 26

${ }^{9}$ FRITZ STEELE, The Sense of Place, CBI Publishing Company, London, 1981, hlm. 28
} 


\subsection{Intention in Architecture}

Pada dasarnya, bangunan memiliki 4 fungsi dalam teori yang bernama The Building Task. Salah satu dari keempat fungsi tersebut adalah physical control. Physical control erat kaitannya dengan hubungan antara bangunan dana lam, sehingga bangunan berperan sebagai pengendali atau pengontrol alam dan lingkungan seperti pengontrol iklim (udara, angin temperatur, kelembapan, curah hujan, dll), suara, bau, hal-hal lain seperti debu, asap hewan, serangga, dan manusia serta radioaktif. Energi-energi yang dimiliki ala mini lah yang harus dikontrol oleh bangunan ${ }^{10}$.

Dalam upaya mengontrol alam tersebut dapat dilakukan dengan berbagai cara seperti mengetahui kemampuan material bangunan sebagai penahan dingin, suara, kelembapan, dll. Penambahan mesin-mesin juga dapat digunakan untuk menciptakan "iklim buatan". Physical control juga dapat dipahami sebagai sebuah "pertukaran energi". Untuk inilah dapat digunakan komponen filter atau saringan, connector atau penghubung, barrier atau pemisah, dan switch atau pengubah ${ }^{11}$.

\subsection{Arsitektur Gereja Katolik}

Kajian mengenai arsitektur gereja, tidak dapat dilepaskan dari gagasan teologisnya; karena ia bukan hanya menjadi landasan teori arsitektur religius, tetapi juga menjadi dasar penerimaan dan penolakan teori atau pemahaman tertentu lainnya. Thomas (1994) mendefinisikan teori arsitektur religius, dalam hal ruang dan tempat, sebagai pemikiran teologis terstruktur mengenai realitas alam semesta. Teori dasar ini berkaitan dengan konsep mengenai alam dan Tuhan, dogma mengenai hubungannya dengan manusia; yang membawa dampak pada cara orang berpikir tentang ruang dan tempat di dunia ini ${ }^{12}$. Meskipun ruang sakral ini dialami berbagai agama dan kepercayaan, tetapi setiap agama mempunyai keunikannya sesuai dasar teologisnya. Selanjutnya kajian arsitektur gereja Katolik menggunakan pendekatan sakralitasnya.

Melalui ritual gereja lah terjadi pembentukan ruang-ruang sakral. Berbagai aktivitas ritual umat baik yang diwadahi di pelataran bangunan gereja, atau di ruang luar gedung gereja, mendukung pembentukan hirarki ruang sakral.

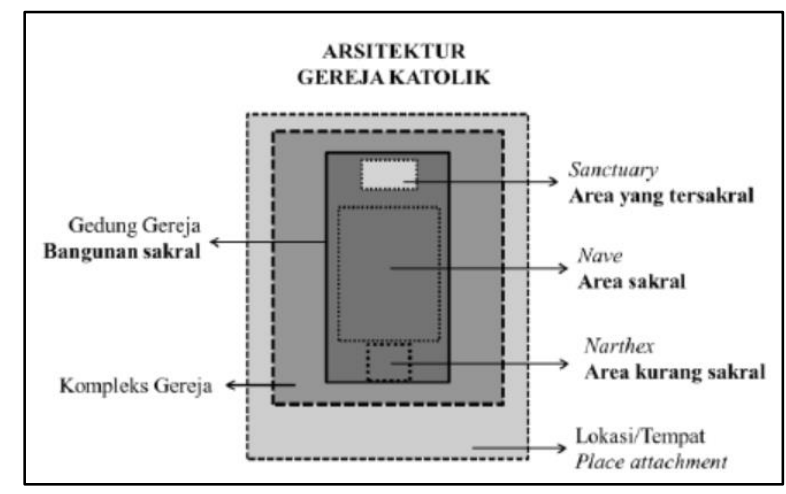

Figur 3. Zoning umum Gereja Katolik Sumber: John Alfred Thomas, 1994

\subsection{Estetika Perkotaan}

\footnotetext{
${ }^{10}$ ALDO ROSSI. Architecture of The City. Massachusetts: MIT Press, 1966, hlm. 23

11 CHRISTIAN NORBERG, Intentions in Architecture, 1997, hlm. 109

12 JOHN ALFRED THOMAS, Theory, Meaning, \& Experince In Church Architecture; University of Sheffield, 1994, hlm. 6
} 
Struktur ruang perkotaan yang direncanakan dengan baik, akan berdampak pada potensi keindahan visual lingkungan. Kunci penentunya selalu terkait dengan nilai-nilai kehidupan lainnya. Nilai pokok kehidupan manusia ada 3, yaitu:

1. Nilai Kebenaran (truth) : seringkali dalam cabang filsafat disebut menjadi ukuran dasar yang disebut logika.

2. Nilai Kebaikan (goodness) : ide pokok dalam cabang filsafat yang biasanya disebut etika.

3. Nilai Keindahan (beauty) : titik pusat cabang filsafat yang disebut estetika.

Kata Estetika berasal dari kata Yunani, aesthetica yang berarti hal-hal yang dapat dicerap oleh pancaindera. Berarti merasakan estetika merupakan pengalaman yang multiindera dan hal tersebut sudah tidak dapat dipisahkan lagi.

Topografi kawasan merupakan elemen geografis perkotaan yang membangkitkan keindahan visual. Semua elemen fisik-spasial akan berkontribusi menciptakan tingkat keharmonisan lingkungan visual. Tetapi keestetikaan tidak hanya diciptakan oleh visual mata saja, tetapi ada dukungan dari indera lain yaitu pendengaran (audial), penciuman, perabaan dan pengecapan karena dengan indah atau baik saja tidak berarti estetis. Berikut dijabarkan matriks substansi pemahaman estetika lingkungan.

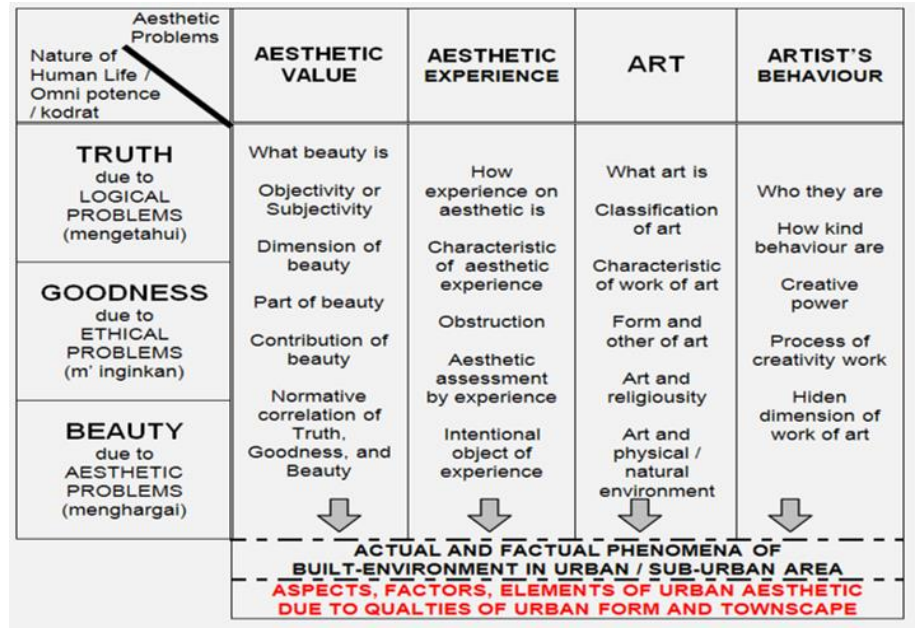

Bagan 2. Nilai-nilai pokok kehidupan manusia

Sumber: Ir. FX Budiwidodo Pangarso, 2018

\section{IDENTIFIKASI ELEMEN ARSITEKTURAL DAN AUDIAL PADA KOMPLEK GEREJA SANTA PERAWAN MARIA SAPTA KEDUKAAN}

Gereja Santa Perawan Maria Sapta Kedukaan atau lebih dikenal dengan Gereja Pandu atau Paroki Pandu merupakan salah satu gereja Katolik tertua di Bandung. Gereja yang berdiri sejak tahun 1935 ini beralamat di Jalan Pandu No 4 Bandung dan terdiri atas dua stasi yakni Stasi Theodorus Sukawarna dan Stasi Caritas Wyataguna, sembilan wilayah, dan empat puluh lima lingkungan.

Komplek Gereja Santa Perawan Maria Sapta Kedukaan berada di daerah Bandung Barat. Terletak di Jalan Pandu, gereja ini berdekatan dengan Jalan Raya Pajajaran yang intensitas kendaraan bermotornya cukup tinggi. 


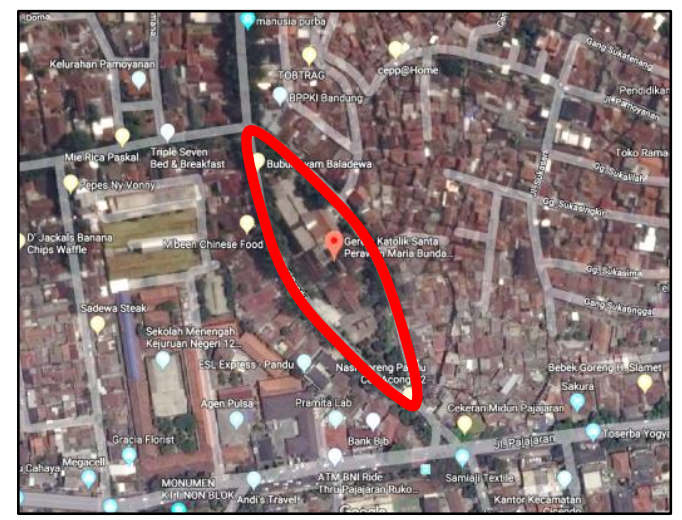

Figur 4. Komplek gereja Santa Perawan Maria Sapta Kedukaan Sumber: Google Earth, Maret 2018

Jika dilihat ruang lingkup kawasan yang lebih kecil fungsi-fungsi yang berada di sekitar komplek Gereja Santa Perawan Maria Sapta Kedukaan pun cukup beragam. Walapun awalnya hanya permukiman biasa, banyak yang beralih fungsi menjadi perdagangan, jasa, dan lainnya.

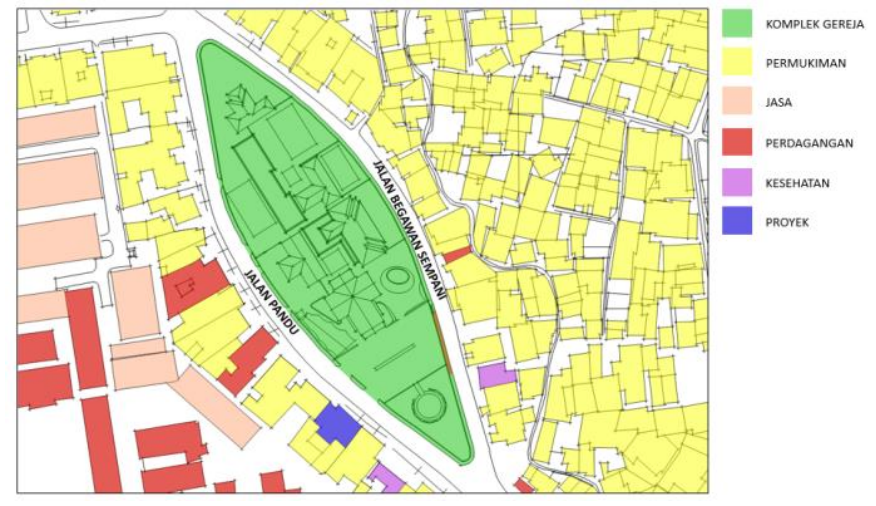

Figur 5. Pemetaan fungsi sekitar komplek gereja

Dilihat dari batasan-batasan ruang yang terjadi, zonasi pada Gereja Santa Perawan Maria Sapta Kedukaan dapat dibedakan menjadi menjadi 3 hirarki ruang (zona) antara lain:

1. Zona Publik : Ditunjukan oleh warna hijau

2. Zona Semi-publik : Ditunjukan oleh warna kuning

3. Zona Privat : Ditunjukan oleh warna merah 


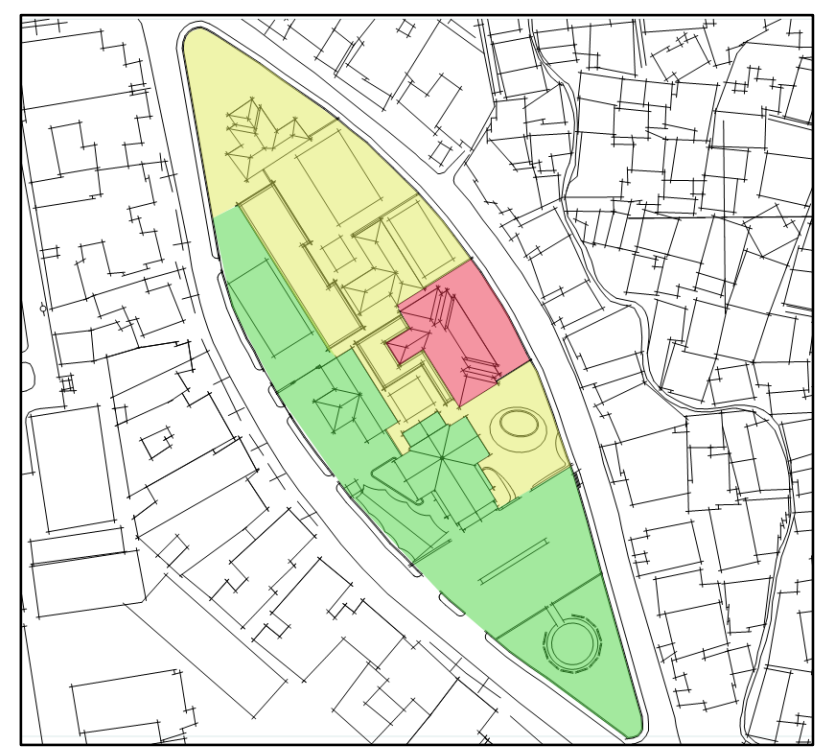

Figur 6. Zoning komplek gereja

Kajian mengenai elemen setting fisik dibagi menjadi hardscape (baik itu elemen horizontal plane maupun vertical plane), softscape, aquaspace, dan perabot jalan. Karakteristik dikaji baik dari aspek bentuk maupun material satu per satu sesuai dengan titik penelitian yang sudah ditentukan.

Berdasarkan titik penelitian itu pun dilakukan pengamatan suara-suara yang terdengar. Suara tersebut dikatergorikan berdasarkan jenis suaranya. Dari hasil pengamatan dapat diihat bahwa suara yang dapat didengar di setiap titik penelitian sangat beragam.

Suara yang terdengar di setiap titik penelitian adalah suara pesawat terbang.

Tabel 1. Data suara

\begin{tabular}{|c|c|c|c|c|c|c|c|c|c|c|c|c|}
\hline \multirow{2}{*}{\multicolumn{2}{|c|}{ Jenis Suara }} & \multicolumn{11}{|c|}{ Titik Penelitian } \\
\hline & & \multirow{2}{*}{$\frac{1}{\sqrt{ }}$} & \multirow{2}{*}{$\begin{array}{l}2 \\
\sqrt{ }\end{array}$} & \multirow[t]{2}{*}{3} & \multirow{2}{*}{$\begin{array}{l}4 \\
\sqrt{ }\end{array}$} & \multirow{2}{*}{$\begin{array}{l}5 \\
\sqrt{ }\end{array}$} & \multirow{2}{*}{$\begin{array}{l}6 \\
\sqrt{ }\end{array}$} & \multirow[t]{2}{*}{7} & \multirow{2}{*}{$\begin{array}{l}8 \\
\sqrt{ }\end{array}$} & \multirow{2}{*}{$\begin{array}{l}9 \\
\sqrt{ }\end{array}$} & \multirow{2}{*}{10} & \multirow{2}{*}{11} \\
\hline \multirow{4}{*}{ Natural Sounds } & Suara burung & & & & & & & & & & & \\
\hline & $\begin{array}{l}\text { Angin menerpa } \\
\text { vegetasi }\end{array}$ & & & & $\sqrt{ }$ & $\sqrt{ }$ & $\sqrt{ }$ & & & & & \\
\hline & Suara serangga & & & $\sqrt{ }$ & $\sqrt{ }$ & $\sqrt{ }$ & $\sqrt{ }$ & & $\sqrt{ }$ & $\sqrt{ }$ & & \\
\hline & Suara air mancur & & & & & $\sqrt{ }$ & & & & $\sqrt{ }$ & & \\
\hline \multirow{4}{*}{ Human Sounds } & $\begin{array}{l}\text { Suara orang } \\
\text { berbincang / } \\
\text { berbisik }\end{array}$ & $\sqrt{ }$ & $\sqrt{ }$ & $\sqrt{ }$ & $\sqrt{ }$ & $\sqrt{ }$ & $\sqrt{ }$ & $\sqrt{ }$ & & & & \\
\hline & $\begin{array}{l}\text { Suara tangisan } \\
\text { anak atau bayi }\end{array}$ & $\sqrt{ }$ & $\sqrt{ }$ & $\sqrt{ }$ & $\sqrt{ }$ & $\sqrt{ }$ & $\sqrt{ }$ & $\sqrt{ }$ & & & $\sqrt{ }$ & \\
\hline & $\begin{array}{l}\text { Suara Imam \& } \\
\text { nyanyian }\end{array}$ & $\sqrt{ }$ & $\sqrt{ }$ & $\sqrt{ }$ & $\sqrt{ }$ & $\sqrt{ }$ & $\sqrt{ }$ & $\sqrt{ }$ & $\sqrt{ }$ & $\sqrt{ }$ & $\sqrt{ }$ & \\
\hline & $\begin{array}{l}\text { Suara orang } \\
\text { batuk / bersin }\end{array}$ & $\sqrt{ }$ & $\sqrt{ }$ & $\sqrt{ }$ & $\sqrt{ }$ & $\sqrt{ }$ & $\sqrt{ }$ & $\sqrt{ }$ & & & $\sqrt{ }$ & $\sqrt{ }$ \\
\hline \multirow{2}{*}{ Sounds \& Society } & $\begin{array}{l}\text { Suara pedagang } \\
\text { kaki lima }\end{array}$ & & & & $\sqrt{ }$ & & & & $\sqrt{ }$ & & & \\
\hline & Suara dari masjid & & & & $\sqrt{ }$ & $\sqrt{ }$ & $\sqrt{ }$ & & & & & \\
\hline Mechanical Sounds & $\begin{array}{l}\text { Suara deru } \\
\text { kendaraan }\end{array}$ & $\sqrt{ }$ & $\sqrt{ }$ & $\sqrt{ }$ & $\sqrt{ }$ & $\sqrt{ }$ & $\sqrt{ }$ & $\sqrt{ }$ & $\sqrt{ }$ & & & \\
\hline
\end{tabular}




\begin{tabular}{|c|l|c|c|c|c|c|c|c|c|c|c|c|}
\hline & $\begin{array}{l}\text { Suara speaker } \\
\text { gereja \& } \\
\text { nyanyian }\end{array}$ & $\sqrt{ }$ & $\sqrt{ }$ & $\sqrt{ }$ & $\sqrt{ }$ & $\sqrt{ }$ & $\sqrt{ }$ & $\sqrt{ }$ & $\sqrt{ }$ & $\sqrt{ }$ & $\sqrt{ }$ & \\
\hline Silence \& Quiet & - & & & & & & & & & & & \\
\hline \multirow{5}{*}{ Sound of Indicator } & $\begin{array}{l}\text { Suara klakson } \\
\text { kendaraan }\end{array}$ & $\sqrt{ }$ & $\sqrt{ }$ & $\sqrt{ }$ & $\sqrt{ }$ & $\sqrt{ }$ & $\sqrt{ }$ & $\sqrt{ }$ & $\sqrt{ }$ & $\sqrt{ }$ & $\sqrt{ }$ & \\
\hline & $\begin{array}{l}\text { Suara pesawat } \\
\text { terbang melintas }\end{array}$ & $\sqrt{ }$ & $\sqrt{ }$ & $\sqrt{ }$ & $\sqrt{ }$ & $\sqrt{ }$ & $\sqrt{ }$ & $\sqrt{ }$ & $\sqrt{ }$ & $\sqrt{ }$ & $\sqrt{ }$ & $\sqrt{ }$ \\
\hline & Suara organ & $\sqrt{ }$ & $\sqrt{ }$ & $\sqrt{ }$ & $\sqrt{ }$ & $\sqrt{ }$ & $\sqrt{ }$ & $\sqrt{ }$ & $\sqrt{ }$ & $\sqrt{ }$ & $\sqrt{ }$ & \\
\hline
\end{tabular}

Metode yang digunakan adalah metode kuantitatif. Data primer yang berkaitan langsung dengan objek penelitian diperoleh dari hasil pengamatan aktivitas, seting fisik dan elemen pada setiap titik penelitian, hasil pengukuran dengan sound level meter, hasil kuesioner, dan wawancara dengan masyarakat, umat, dan pastur gereja. Data sekunder didapatkan melalui studi literatur dan dokumen Gereja Santa Perawan Maria Sapta Kedukaan untuk gambar kerja seperti denah kawasan, denah gedung, tampak, dan potongan.

\section{HUBUNGAN SOUNDSCAPE DENGAN PENDENGAR \& ELEMEN ARSITEKTURAL}

Selain fungsi-fungsi di sekitar komplek gereja yang mempengaruhi soundscape, posisi komplek terhadap sekitarnya menciptakan suatu pengalaman ruang audial (soundscape) tersendiri. Dalam hal ini, bentuk komplek yang seperti delta tersebut berpotensi menerima bising yang bersifat sentrifugal (mendekati titik pusat). Ditambah lagi dengan suara pesawat terbang yang melintas di atas komplek gereja menambah keunikan soundscape komplek gereja ini. Hal ini membuat sumber bunyi yang terdengar di Komplek Gereja Santa Perawan Maria Sapta Kedukaan cukup beragam dengan karakteristik yang bermacam-macam. Berikut ini adalah sumber-sumber suara dari kawasan yang terdengar di dalam Komplek Gereja Santa Perawann Maria Sapta Kedukaan:

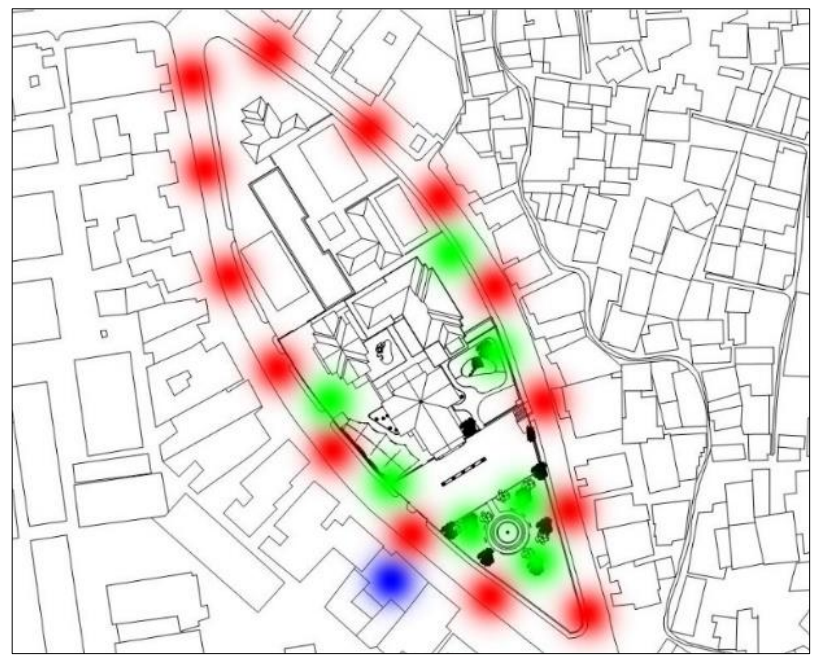

Suara Serangga

Suara Kendaraan

Figur 7. Sumber suara secara horizontal 

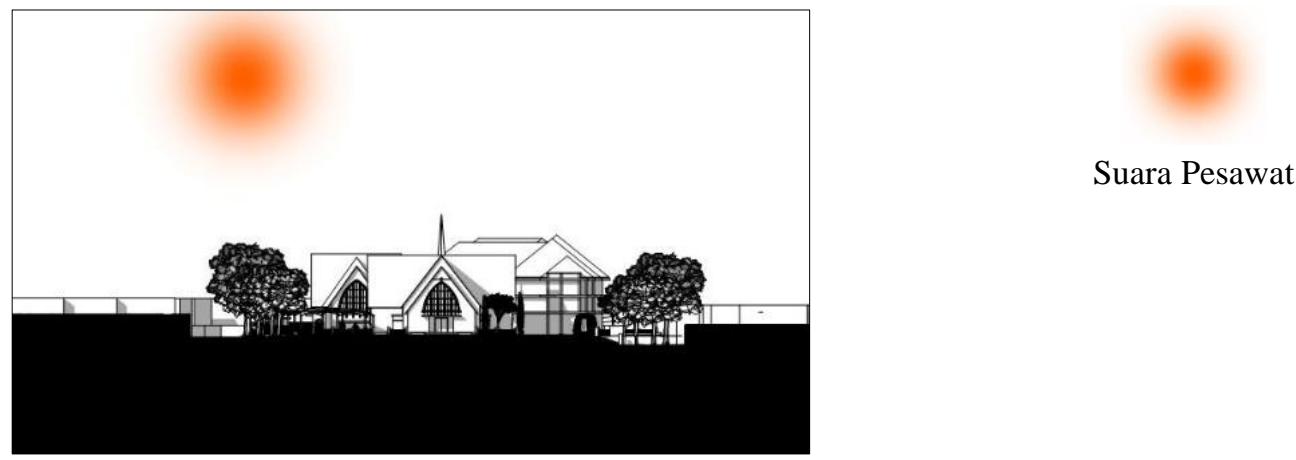

Figur 8. Sumber suara secara vertikal

Berdasarkan hasil kuesioner mengenai persepsi pendengar terhadap suara yang ada di komplek gereja dan hasil wawancara terhadap beberapa pastur dan warga sekitar didapatkan pengkategorian suara-suara yang terdengar mulai dari suara yang sangat sesuai dengan penciptaan suasana sakral sampaisuara yang dianggap sangat mengganggu. Suara yang paling dominan dan bisa didengar baik hari biasa maupun akhir pekan atau pagi maupun sore adalah suara pesawat terbang.

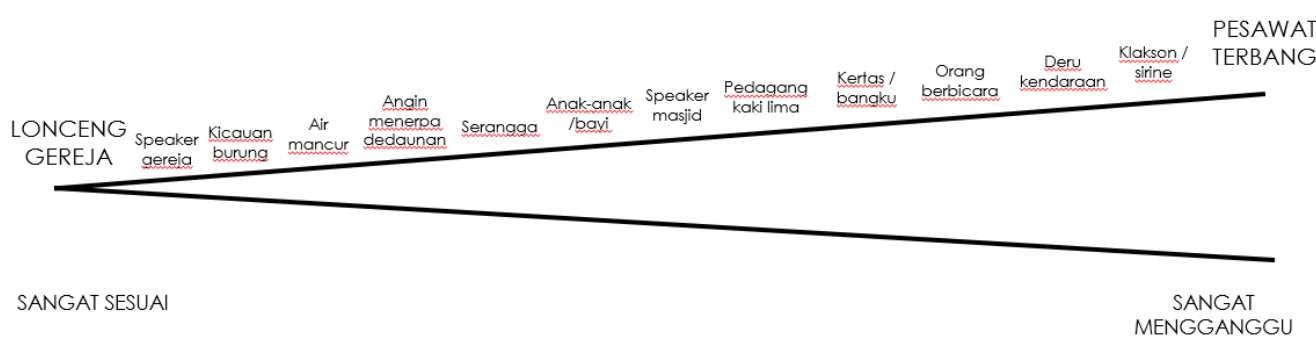

Bagan 3. Persepsi pendengar terhadap suara-suara di komplek gereja

Selain mendapat mendapat pengaruh dari suara-suara lingkungan, kehadiran Gereja Santa Perawan Maria Sapta Kedukaan juga mempengaruhi soundscape di lingkungan sekitarnya. Suara-suara yang dihasilkan oleh kehadiran Gereja Santa Perawan Maria Sapta Kedukaan antara lain suara lonceng, speaker gereja, dan nyanyian atau doa.

Lonceng gereja berbunyi setiap hari pada pukul 06.00, 12.00, dan pukul 18.00 yang menandakan waktu untuk berdoa doa 'Malaikat Tuhan'. Selain itu lonceng gereja juga berbunyi 30 menit sebelum misa dimulai pada hari Sabtu dan Minggu. Hari Sabtu lonceng berbunyi pukul 17.00 sedangkan hari Minggu lonceng berbunyi pada pukul 05.00, 06.45, 08.45, dan 17.00. 


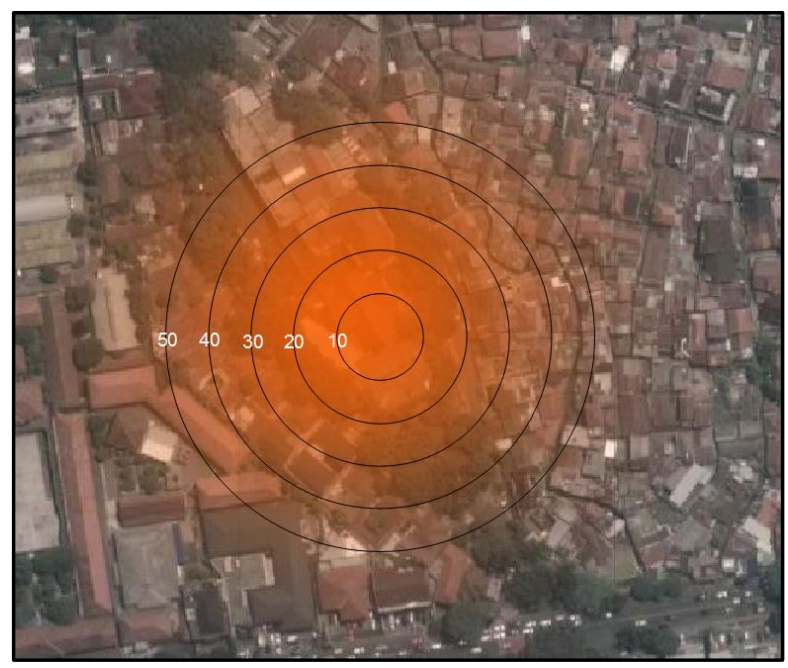

Figur 9. Radius penyebaran suara lonceng gereja

Fungsi yang berada di dalam komplek gereja umumnya membutuhkan kenyamanan audial yang baik dan relatif hening baik misa, berdoa di goa maria, pieta, kapel adorasi dan melakukan pengakuan dosa. Dengan begitu, kesesuaian tata letak fungsi terhadap sumber kebisingan merupakan hal yang penting dan perlu dipikirkan.

Dilihat dari lokasinya, suasana permukiman warga sangat cocok untuk tempat peribadatan seperti Gereja Santa Perawan maria Sapta Kedukaan. Lingkungan yang masih asri dan jumlah pohon peneduh yang cukup banyak mendukung suasana tempat ibadah yang bersifat kontemplatif. Berbeda dengan lokasi gereja yang berada di pusat kota dimana banyak aktivitas yang terjadi dan mobilisasi sangat tinggi berpengaruh terhadap penciptaan suasana tempat ibadah. Walaupun kendaraan yang melintas tetap ada namun intensitasnya tidak setinggi di pusat kota.

Selain dari segi kendaraan bermotor, faktor alam juga berpengaruh terhadap penciptaan soundscape pada lokasi Gereja Santa Perawan maria Sapta Kedukaan. Suara burung dan serangga dapat dengan mudah didengar pada gereja ini. Suara-suara tersebut dapat menjadi potensi untuk meningkatkan kualitas soundscape pada Gereja Santa Perawan Maria Sapta Kedukaan.

Dilihat dari elemen sirkulasinya, Komplek Gereja Santa Perawan Maria Sapta Kedukaan ini dikelilingi oleh Jalan Pandu dan Jalan Begawan Sempani. Pada bagian Utara komplek terdapat percabangan jalan berupa perempatan antara Jalan Pandu, Jalan Begawan Sempani, dan Jalan Pesantren Wetan sedangkan pada bagian Selatan terdapat pertemuan antara Jalan Pandu dengan Jalan Padjajaran. Karena letaknya yang berada di daerah permukiman, batas elemen utama di sekeliling komplek adalah bangunan rumah satu sampai tiga lantai sedangkan elemen sekunder berupa vegetasi pada sisi jalan yang mengitari komplek gereja.

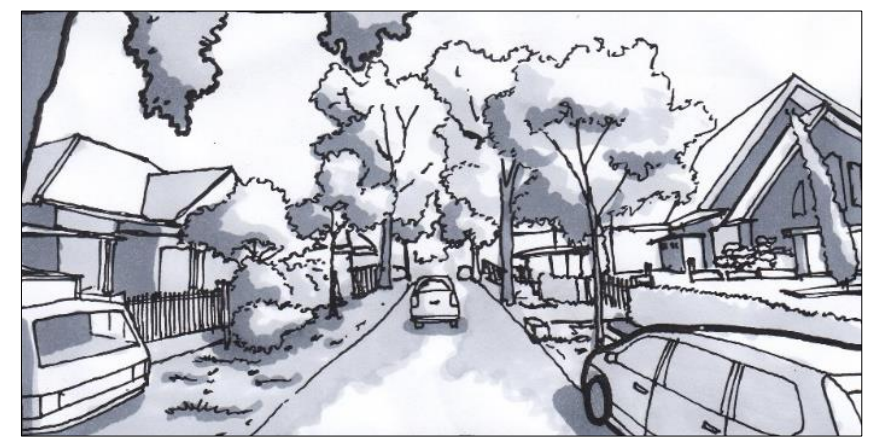


Figur 10. Suasana Jalan Pandu

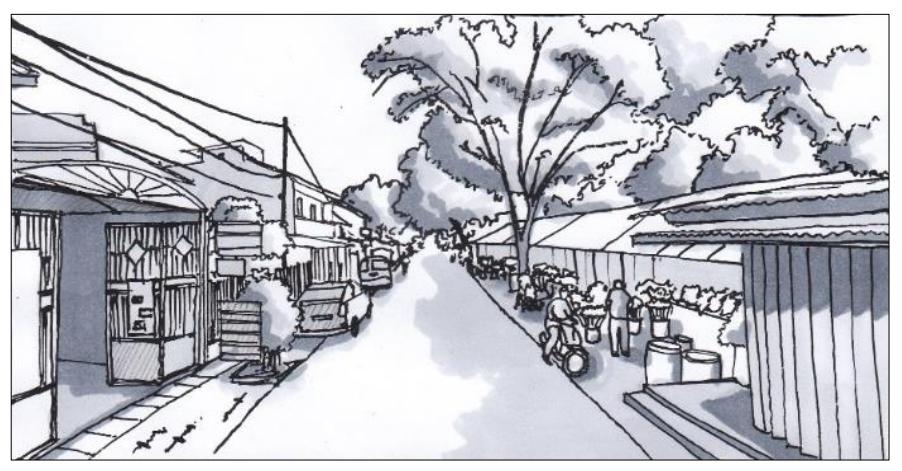

Figur 11. Suasana Jalan Begawan Sempani

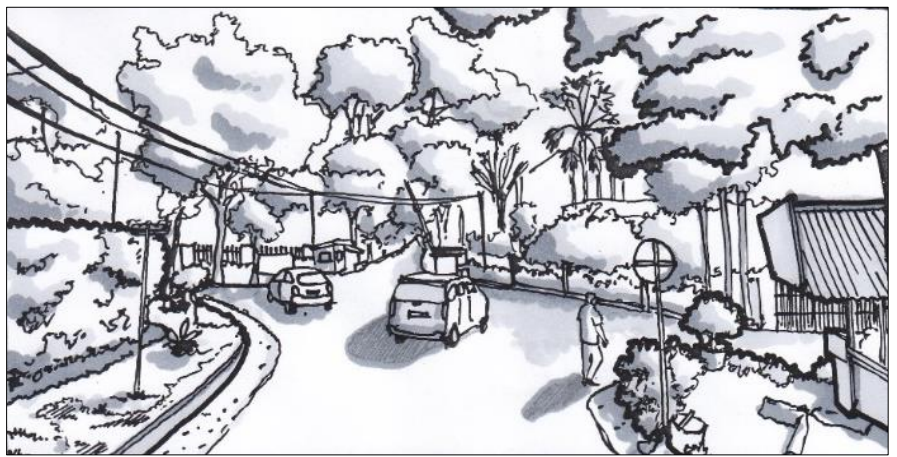

Figur 12. Suasana Persimpangan Jalan Pandu, Begawan Sempani, dan Pesantren Wetan

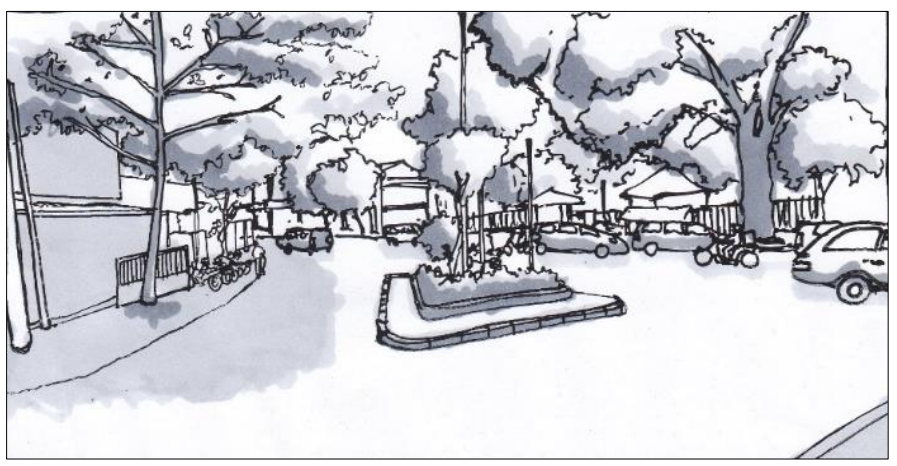

Figur 13. Suasana Persimpangan Jalan Pandu dan Padjajaran

Bentuk komplek yang disekitari oleh jalan raya membuat bising kendaraan bermotor mengelilingi komplek gereja. Dengan begitu titik yang paling jauh dari bising kendaraan bermotor berada di tengah komplek. Namun hal ini tidak menjadikan semua fungsi peribadatan harus berada di tengah tapak. Hal ini bergantung juga pada skala prioritas peruntukan fungsi ruangnnya.

Tabel 2. Kesesuaian bentuk dan karakter fisik komplek gereja

\section{Bentuk \& Karakter Fisik Komplek Gereja \\ Bentuk \& Karakter Fisik yang Dibutuhkan}




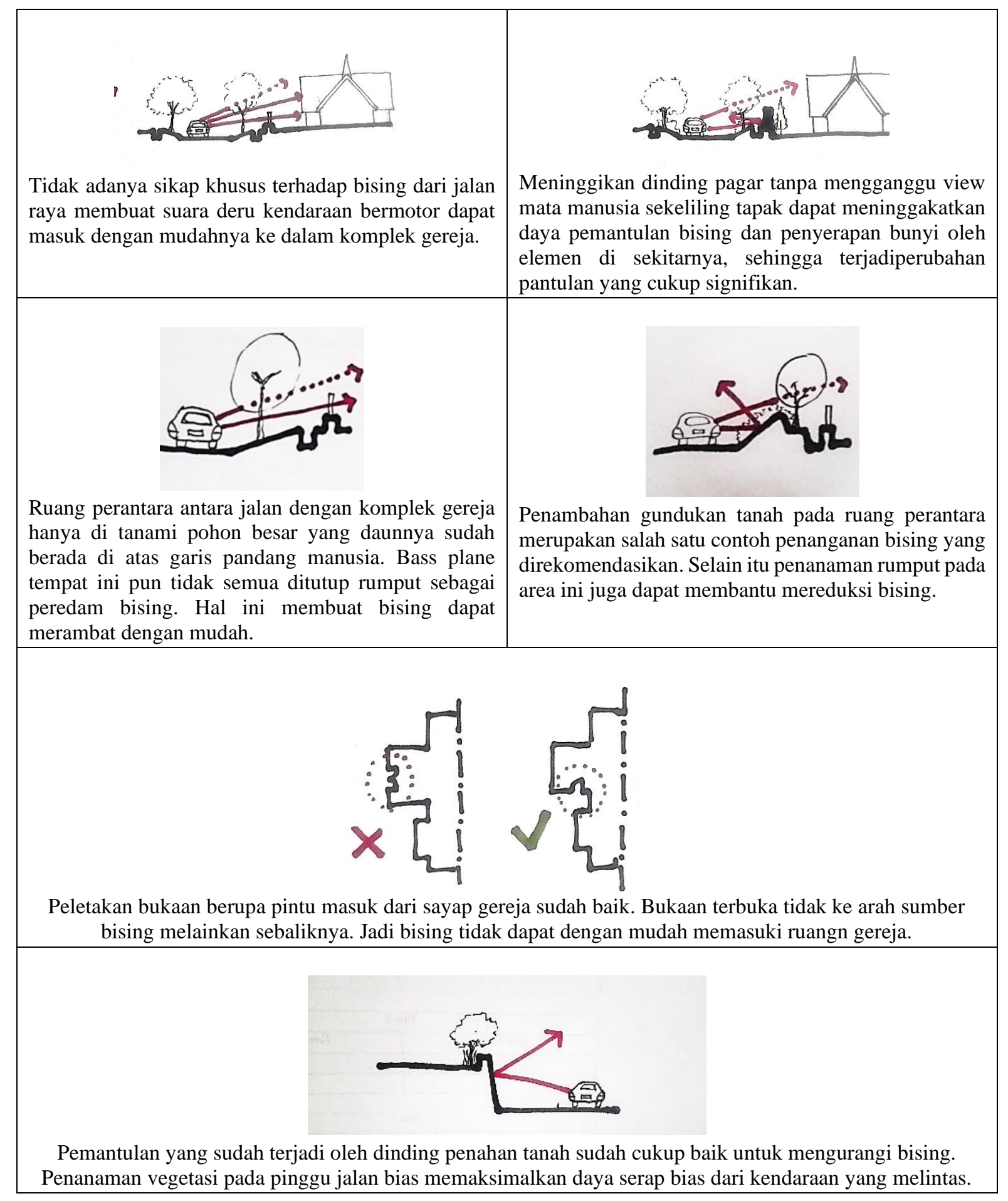

Tabel 3. Kesesuaian elemen arsitektural pada komplek gereja

\begin{tabular}{|c|c|}
\hline $\begin{array}{c}\text { Elemen Arsitektur pada Komplek } \\
\text { Gereja }\end{array}$ & Elemen Arsitektur yang Dibutuhkan \\
\hline
\end{tabular}




\begin{tabular}{|c|c|}
\hline $\begin{array}{l}\text { Secara audial, pagar besi tidak berperan } \\
\text { banyak dalam penanganan bising. Bising } \\
\text { dapat dengan mudah melewati celah- } \\
\text { celah besi. Namun secara visual pagar } \\
\text { yang hanya memiliki tinggi } 1.2 \text { meter ini } \\
\text { memudahkan mata untuk melihat } \\
\text { sekeliling. }\end{array}$ & $\begin{array}{l}\text { Penggunaan vegetasi berguna untuk } \\
\text { menyaring bising dari luar. Agar } \\
\text { pandangan mata manusia tetap terjaga, } \\
\text { digunakan tanaman yang memiliki } \\
\text { ketinggian di atas } 1.8 \text { meter atau di } \\
\text { bawah } 1.2 \text { meter. Jadi bising dapat } \\
\text { tersaring tanpa merusak pandangan } \\
\text { mata. }\end{array}$ \\
\hline $\begin{array}{l}\text { Pagar tanaman bambu sudah digunakan } \\
\text { di beberapa titik komplek gereja untuk } \\
\text { menyaring bising namun } \\
\text { penggunaannya kurang efektif. Masih } \\
\text { banyak celah yang memungkinkan } \\
\text { bising bisa melewatinya. }\end{array}$ & $\begin{array}{l}\text { Pagar tanaman bamboo dibuat dengan } \\
\text { kerapatan yang lebih baik sehingga } \\
\text { penyaringan bising oleh vegetasi dapat } \\
\text { dilakukan dengan maksimal. }\end{array}$ \\
\hline $\begin{array}{l}\text { Titik-titik bukaan pada dinding gereja } \\
\text { menjadi potensi masuknya bising. Suara } \\
\text { bahkan tidak tersaring terlebih dahulu. }\end{array}$ & $\begin{array}{l}\text { Penataan vegetasi berupa perdu di dekat } \\
\text { bukaan dinding gereja berungsi sebagai } \\
\text { penyaring bising sebelum akhirnya } \\
\text { memasuki gereja. Dengan begitu besaran } \\
\text { bising yang masuk lebih rendah. }\end{array}$ \\
\hline
\end{tabular}




Penggunaan genteng tanah liat blm cukup maksimal
untuk meredam bising terutama suara pesawat terbang
yang bersumber dari atas namun celah antara genteng
dan plafond meredksi bising.

\section{KESIMPULAN}

Kesimpulan di bawah ini merupakan jawaban dari beberapa pertanyaan penelitian yang sudah dinyatakan dalam bab pendahuluan

Hal mendasar yang berpengaruh terhadap pengalaman soundscape pada Komplek Gereja Santa Perawan Maria Sapta Kedukaan Bandung adalah setting lokasi dan persepsi setiap pengunjungnya. Sebagai tempat ibadah umat Katolik, gereja ini menghadirkan pengalaman soundscape yang berbeda dengan gereja lainnya. Keberadaannya di dekat Bandar Udara Husein Sastranegara Bandung membuat gereja ini kerap kali dilewati pesawat terbang. Tidak hanya kekuatan suaranya yang cukup kuat, namun intensitas pesawat yang melintas juga cukup tinggi khususnya di pagi dan sore hari.

Hal ini tentunya mempengaruhi persepsi pengunjung akan soundscape yang tercipta. Lokasi gereja yang berada di sekitar permukiman warga masih tergolong asri dan hijau sehingga dapat terdengar suara burung dan suara serangga dalam intensitas yang tinggi pula. Pengunjung beranggapan bahwa mereka dapat mentoleransi suara pesawat yang melintas. hal itu dikarenakan di samping suara pesawat yang tergolong mengganggu, masihh ada suara-suara 
lain yang bahkan mendukung dan meningkatkan sacred feeling Gereja Pandu yakni suara burung, serangga, dan lonceng gereja

Suara yang paling dominan yang dihasilkan oleh gereja adalah suara lonceng. Berdasarkan opini dari warga sekitar, suara lonceng tersebut tidak mengganggu aktivitas keseharian mereka. Suara lonceng gereja dimanfaatkan warga sekitar khususunya para pedagang sebagai tanda penunjuk waktu baik untuk bersiap-siap berjualan maupun membereskan jualannya. Warga sekitar gereja dapat mentoleransi kencangnya suara lonceng karena menurutnya suara lonceng sama seperti suara adzan dalam agama Islam. Keduanya memiliki maksud yang baik untuk mengingatkan umatnya untuk beribadah.

Elemen arsitektural berperan penting dalam penciptaan pengalaman soundscape. Hubungan keduanya dikaji melalui karakteristik elemen arsitektural beserta kinerjanya terhadap soundscape yang terbentuk. Usaha Gereja Santa Perawan Maria Sapta Kedukaan untuk menciptakan penglaman soundscape yang maksimal saat beribadah dan terhindar dari bising dapat terlihat dari peletakan massa gereja yang berada di tengah-tengah tapak. Hal ini bertujuan untuk menjauhkan gereja dari jalan sebagai sumber bising.

Elemen-elemen arsitektural pada komplek gereja seperti pagar besi dinilai belum cukup efektif untuk menangani bising. Potensi penggunaan dan penyusunan vegetasi sebagai penciptaan soundscape yang ideal belum dilakukan dengan semaksimal mungkin seperti penggunaan susunan pohon bamboo untuk menyaring bising kendaraan bermotor belum maksimal dikarenakan jarak antar pohonnya yang masih terlalu jauh dan ketinggian pohon bambu yang hanya 1.5 meter.

Secara garis besar, Gereja Pandu sudah mulai peduli terhadap penciptaan pengalaman soundscape dan pengendalian bising melalui elemen arsitektural penyusunnya namun belum maksimal.

Berdasarkan substansi pemahaman estetika lingkungan, diperlukan keseimbangan antara nilai kebeneran, kebaikan, dan keindahan. Keseimbangan ketiga nilai tersebut pun harus harus dilihat dari multi-sensory experience yang tercipta. Pada penelitian ini akan difokuskan pada aspek auditory experience.

Setelah dikaji, keterhubungan elemen arsitektural dengan soundscape di Gereja Santa Perawan Maria Sapta Kedukaan belum bisa dikatakan estetis karena belum memenuhi ketiga parameter nilai estetis.

Pengalaman soundscape pada Gereja Santa Perawan Maria Sapta Kedukaaan belum dikategorikan baik karena masih adanya beberapa suara yang mengganggu pengalaman suara seperti suara pesawat, klason, dan deru kendaraan bermotor.Penggunaan elemen arsitektural untuk penciptaan soundscape yang baik belum maksimal. Pemanfaatan vegetasi untuk mereduksi bising hanya diaplikasikan di beberapa titik saja.

Jadi, hubungan soundscape dengan elemen arsitektural Gereja Santa Perawan Maria Sapta Kedukaan belum terpenuhi dengan indah, baik dan benar terhadap estetika perkotaan.

\section{Acuan}

GREGORY, RICHARD. (1974). Concepts and Mechanisms of Perception. London: Duckworth

KRAUSE, BERNIE. (1987) Soundscape Ecology: The Science of Sound in the Landscape. Indiana: Purdue University.

PALLASMAA, JUHANI. (1996). The Eyes of The Skin. Helsinki:Wiley

RM, SCHAFER. (1977). The Tuning of The World. New York: Alfred A. Knopf.

ROSSI, ALDO. (1966). Architecture of The City. Massachusetts: MIT Press

SCHACTER, DANIEL. (2011). Psychology. New York: Worth

SCHULZ, CHRISTIAN NORBERG. (1997), The Building Task; Intentions in Architecture. Massachusetts: MIT Press. 
STEELE, FRITZ. (1981). The Sense of Place. London: CBI Publishing Company.

SUTANTO, HANDOKO. (2015). Prinsip-prinsip Akustik dalam Arsitektur. Yogyakarta: PT. Kanisius.

THOMAS, JOHN ALFRED, (1994). Theory, Meaning, \& Experince In Church Architecture; University of Sheffield

TRUAX, B. (1978). Handbook for Acoustic Ecology. A.R.C. Vancouver, Canada: World Soundscape Project Publication.

http://keuskupanbandung.org/main/Cat/8 